\title{
Migrant Labourers' Struggles Between Village and Urban Migration Sites: Labour Standards, Rural Development and Politics in South India
}

\author{
David Picherit, Centre for South Asian Studies - EHESS Paris
}

\begin{abstract}
This article examines seasonal labour migrants' social and spatial engagement with contemporary transformations in labour migration patterns, State policies and development issues in the South Indian state of Andhra Pradesh. This state is at the forefront of the neo-liberal policies that have been rolled out in India since the 1990s.

By looking at shifting temporalities, spaces and forms of labour contestation in South India, it considers how the forms, spaces and focuses of struggles of migrant labourers in the village and urban construction sites shape and are shaped by State policies which silence capital/labour issues in favour of development/poverty perspectives, village power relationships and the organization of the urban construction industry.

Based on ethnographical fieldwork carried out with seasonal migrant labourers, both in their home village and in urban construction sites where they are employed as casual labourers, this article argues that the focus of labourer's struggles is on village based social outcomes rather than on workplace issues. This is related to the absence of government labour regulation standards and rights within the city and to the flow of developments schemes in rural settings, cornered and redistributed by local leaders under logics of clientelism.
\end{abstract}

\section{KEYWORDS}

construction industry, India, labour migration, labour struggles, rural development

\section{Introduction}

This paper examines seasonal labour migrants' social and spatial engagement with contemporary transformations in labour migration patterns, State policies and development issues in the South Indian state of Andhra Pradesh. This state is at the forefront of the neo-liberal policies that have rolled out in India since the 1990s.

It argues that the forms, spaces and focuses of struggles of migrant labourers in the village and urban construction sites shape and are shaped by State policies, which silence capital/labour issues in favour of development/poverty perspectives. I will examine how the focus of labourer's 
struggles on village based social outcomes rather than on workplace issues, but also everyday forms of consent, adaptation, fear and resistance, are embedded into the interrelationship of village power hierarchies, development schemes and the organization of the urban construction industry.

The decline of patronage, the effects of neo-liberal policies and reduced State intervention are main arguments in debates on contemporary transformations of labour relations in India. Such discussions have highlighted the informalisation of the economy, casualisation of the labour force and increasing labour mobility (Breman 1996, Srivastava and Sasikumar 2003, Breman et al. 2009). The construction industry is a double-digit growth sector that has been sustained by public funds and public-private partnerships while also relying on highly mobile migrant labourers. This sector is celebrated by the Indian Planning Commission, because it (i) absorbs rural labour and unskilled workers; (ii) provides opportunity for seasonal employment thereby supplementing workers' income from farming; and (iii) permits large-scale participation of women workers' (Indian Planning Commission 2007: 848). This migrant workforce, employed in a profitable construction sector which has not implemented the official labour standards, is rural, unskilled and seasonal, and relies on rural settings for decent income and social outcomes.

To investigate the regulation of government labour standards in informal economy, one must consider the whole gamut of State interventions, from labour to development related ones; from workplaces, urban living spaces to villages of origin, and its relations to the construction industry and the labour migrants' management.

Over the past 15 years, the limited scale of attempts to regulate the informal economy by States 'which possess the power of enforcement, [but] actually choose not to exercise it' (HarrissWhite 2010) has been reinforced by a strong stance against labour (Lerche 2007). Central and regional states have instead launched a number of schemes, programmes and Bills relating to work, health and livelihoods (such as the National Rural Employment Guarantee Act, Aarogya Sri) in rural areas, which do address poverty, but not redistribution (Bowles 2010: 23).

It is no coincidence that the Telugu Desam Party (TDP) ${ }^{1}$ government in Andhra Pradesh ${ }^{2}$ has pushed through development related issues since the 1990s. It has pursued an anti-labour agenda, promoted the Special Economic Zones and the implantation of multinational companies in HITECH City, while launching a number of assistance schemes for select groups based on electoral considerations (Srinivasulu 2002). Andhra Pradesh, as India's biggest microfinance state in terms of clients, financial activities and institutions (Augsburg and Fouillet 2010) may be most representative of such policies ${ }^{3}$, which could be argued to stamp out calls for improved salaries and working conditions. They instead focus on 'educating' the poor to save them from low salaries, to ensure financial inclusion (Guérin et al. 2009) and to shift solidarities by barely giving individuals a voice (Pattenden 2005) ${ }^{4}$. The shift from capital-labour to development - antipoverty State policies takes the form of the abandoning of formal sector as a model, and a move towards the promotion of informality, responsibility-making guilty of the working poor, and selfhelp. It has a resonance at the village level where contestations of debt-bondage in favour of daily wage employment in 1990s have turned into struggles for development outcomes related to the absence of labour standards in urban construction industry.

This article is based on 24 months ethnographical fieldwork focussing on Golla caste seasonal migrant labourers, both in their village in the district of Mahabubnagar (Andhra Pradesh), and in an area called Lalapet in Hyderabad where they are employed as daily wagers in the urban construction industry. It firstly examines their socio-spatial strategies for creating and 
preserving access to a labour market niche that affords them access to the urban facilities of Hyderabad. It secondly analyses their efforts to participate in the social and political rise of their caste in their home village. Here, they are politically active in a bid to access local development and state resources, which, till now, have been cornered by local leaders and unequally redistributed.

Scholars have highlighted the growing politicisation of low castes and the use of political patronage to cope with everyday problems in urban (Gooptu 2007, Harriss 2005) and rural settings (Byres et al. 1999, Robinson 1988) and its mechanisms of mediation (Price and Ruud 2010). In a context where migration is at the core of the social, political and economical life of the village (Mosse 2005) as well as in the urban construction industry I argue that political clientelism, migration and labour struggles and standards, or the relations between labour, development and politics, should be analysed in situ, by taking into account the multiple sites where migrant labourers live and work from urban to rural sites. Lerche (2010) rightly argues that urban or rural are less significant for classes of labour than segmentation, and I will point to how Gollas migrants' struggles in villages and construction sites are interrelated. By examining shifting temporalities, spaces and forms of labour contestation in South India, I will consider how absent State labour regulation standards in the construction industry, indirect labour management and a development programme flow cornered by leaders and political parties cause labourers to struggle not over capital, but over policies and development projects in rural settings.

Golla migrant labourers' shifts between keeping a low profile in their workplaces and openly raising political demands in their village partly stem from their caste's political rise and the viability of their traditional activity as goat keepers, but also their past experiences as debt-bonded labourers. It is also due to local leaders appropriating and redistributing development schemes, and the impossibility for these migrants of settling in urban areas. Labour and recruitment processes depend on a turnover of labourers who are willing to work for low salaries, while keeping a low profile and proving their docility.

The article therefore discusses how discipline in urban settings is turned to an advantage in the village of origin. De Neve approaches discipline not just as a response to the expectations of management, but also in relation to workers' aspirations for urban work and life, and the chance to at least partly meet these aspirations within a specific organisation, and 'the extent to which the migrant workers succeed in locally constructing and mobilizing the support of networks and patrons' (2003: 253). With their aspirations centred on village issues, labourers engage with new forms of micro-hierarchies in the Hyderabad labour market in order to maintain a group position in the urban informal economy and their village, trying to reframe their experiences to their advantage. This is similar to the concept of rural cosmopolitan proposed by Gidwani and Sivaramakrishnan (2003). This paper describes how labourers reframe their dependencies by highlighting their capacity to negotiate various hierarchies and to migrate out of the labour bondage system, mobilising this ability in order to challenge village caste and power relationships.

\section{Caste, Social Rise and Informal Regulation of Migration}

Peddapur is a village of over 2500 people in Telangana, a drought-prone area historically known for being dominated by a variety of local landlords (Frykenberg 1977, Thirumali 2003). Its power relationships are based on an overlap of caste, land ownership and politics, and are 
exemplified by the local debt-bondage system, Palamur, which originated in the 1930s. Local leaders of the Reddy landowner caste have secured numerous public contracts, using maistri (labour middlemen) to send labourers to major national projects such as dams, canals, roads and stone quarries. Maistri are key figures in this system, forwarding advances to labourers, locating worksites and housing, and supervising the progress of work.

While the nature of local patronage has been transformed, the Reddys have maintained indirect control over labour issues, as well as direct control over political and development programmes, whether launched by State, NGOs or international agencies. The current head of the village, the peddamanishi ${ }^{5}$, is the latest of a long line of leaders. He is the main landowner, a former maistri, the head of the regionalist Telugu Desam party at the mandal level, and a highly influential figure in every kind of development activity. He is closely connected through kinship to Members of the Legislative Assembly (MLA) and a Congress Party ${ }^{6}$ Member of Parliament (MP), while his two sons work in the construction industry in the tipper business. One of them, who lives 500 kilometres away from Peddapur, became the head of the grampanchayat in 2009. Those kinship links soften the political factions between Reddy households, as did the defeat of TDP in 2004 at State level (TDP keeps power at the intermediate district level). Locally, the hereditary position of the head of the village is hardly challenged by mute Congress members. Nonetheless, these local leaders' historical presence cannot hide the deep contemporary social, political and economic changes, and the conflicts with low castes that are currently playing out.

Since the 1980s the Reddys have had to contend with the Gollas, who have benefited the most from these transformations, and who became involved in politics through the regional party Telugu Desam (TDP), whose electoral base consists of low-castes. Some Gollas became maistri within the debt-bondage system, while many seasonally migrated for daily wages in Hyderabad. The Gollas' access to Panchayat, their land investments and lucrative goat rearing activities have helped to ensure their stable political and economic base.

The Gollas' upward mobility is still fragile however, and there have been growing internal differentiation. Labourers' refusal of personalised labour attachment relations has been matched by their bosses' refusal to bear the social and economic costs of labour protection. The Gollas began to turn to maistri just when such disengagement began. Migrating for daily wages meant being absent from the developmental and political life of the village for nine months a year. Their land investments were often no more than token ones, as the head of the village comments:

'Agriculture is no longer profitable. There is no water, I had to sell my cattle last year, and there is nothing to eat. We are Reddy, we are landowners, but only politics is profitable. We sell land to Gollas and to others, but what can they do with it? They work in construction, so what do they know about agriculture'?

While the Reddys maintain dominance in the village, the Gollas combine their traditional activities, the maistri and their income from migration in order to consolidate their local position with respect to both the Reddys and other castes. Rising up within these micro-hierarchies has meant keeping others down (Herrenschmidt 2004), including the Madigas who have no access to political life and who suffer from considerable caste discrimination. 60 percent of Madiga labour migrants are debt-bonded labourers, as opposed to 25 percent of Golla migrants. A further 50 percent of Golla migrants travel as daily wagers to Lalapet and 25 percent commute between the village and the nearby town to work on small jobs. Up to 80 percent of the village's households 
have at least one migrating member, including the Gollas, although there is a high level of seasonal variation owing to the monsoon. The Madigas rarely migrate as daily wagers, although their numbers are increasing as young people look to escape from agricultural work.

Casual labour migration to Hyderabad has transformed labour relations and fostered a form of social mobility. Golla Tankeranna, an elderly former debt-bonded labour migrant, affirms that these changes date from 1982 when the TDP gained power in Andhra Pradesh:

'Everything changed in the village with N. T. Rama Rao: a road was built, the bus came and also electricity. My grandchildren now migrate to Lalapet. I used to walk to Wanaparthy ${ }^{7}$, but everything is easy now, we eat rice every day and Reddys give us respect'.

Tankeranna worked as a debt-bonded labourer in the 1950s from the age of 12, migrating all over India under Reddy maistri management. Until 1985, his wife and children accompanied him on foot, by bullock-cart or train from Karnataka to Bihar and Goa, working at mines, on canal projects, dams and railway tracks, digging earth and carrying stones.

The political transformations were the opportunity for the Gollas of the taluk of Wanaparthy to develop an exclusive migration stream. The Gollas have forged an economic niche for the construction sector in the neighbourhood of Lalapet in Hyderabad, which has had to be secured and developed. Access to the niche is regulated through a set of informal, oral and dynamic rules and the restriction of information. Labour market fragmentation in Hyderabad is determined by geographic origin (taluk), caste and class.

Lalapet labourers' profiles vary. Many were once daily wagers but then became debtbonded labourers, before working again as daily wagers. They may also undertake agricultural work in the village, cultivating small acres of dry land, or purchasing goats for few months. Others remain in the village for few years, and then work for cash for a season in Lalapet. These profiles highlight the fluidity of labour forms, which shift between debt-bondage and daily-wage along a continuum of classes of labour (Lerche 2010).

Tankeranna's family managed to establish a strong network in Lalapet. His grandsons Daseratta, Balaswamy, Venkataïah, Srinu and their wives work in Hyderabad and live in different huts in the courtyard of houses owned by S.C. ${ }^{8}$ employees of the railway company to which they are dispatched.

Golla labourers continuously negotiate their social position and networks of kinship and friendship in the village in order to access, maintain and pass over their jobs. Krishnaïah is a neighbour of Tankeranna's family and grew up with Daseratta, where they herded goats together in the fields. Krishnaïah worked as debt-bonded labourer for five years before becoming a hamali ${ }^{9}$ in Wanaparthy with his brother. Labourers with family support are in a position to move from debt-bondage to daily-wage work. Meanwhile some families may send one son as daily wager and another as a debt-bonded labourer to obtain a large sum of interest-free money.

This friendship with Daseratta has offered some guarantees:

'Hamali is a very hard work, I sleep there in the warehouse. I prefer Lalapet, salaries are better and I know some people. I want to buy goats and I need money, I would work three years while my brother would stay in the village. Daseratta would help me in any case and the entire village is there'. 
The pair's friendship is both affective and instrumental. Daseratta would never forget to remind his friend of their service-relationship of dependence, which extends to their respective families.

Krishnaïah prefers the friendship option to the family one. For instance he criticises his uncle Idanna, a debt-bonded labour, whose two daughters work in Lalapet:

'Wherever he goes, he creates trouble, complains and drinks a lot. He may tell the truth but he always want to quarrel. I do not want any trouble, even his daughters complain when he visits them'.

Krishnaïh is clearly aware that avoiding problems is key to accessing Lalapet. Such docility was largely picked up through his previous experience of debt-bondage.

A year and a half later, he had become established in Lalapet. As a jovial, loyal and hard worker, he had forged a close relationship with the local maistri, and was even in charge of a machine, a prestigious position. This made him a reliable intermediary for Gollas wishing to try their luck in Lalapet. He was able to recommend Saodanna, a shepherd, and his wife, an agricultural labourer, who were in need of cash to pay back a debt taken out for a winnower.

Krishnaïah, a former debt-bonded labourer with the dream of buying goats, and Saodanna, an established Golla in need of cash, are representative of the social backgrounds and the aspirations of migrant labourers in Lalapet. Daily-wage work is never an end in itself, but a transitional role between debt-bondage and the most prestigious activity for the Gollas, an anticipated future as a village goat keeper. Their aspirations are wholly focused on their life in the village.

No one migrates to Lalapet without being sure of a job, which requires the short-term influence of a worker over a maistri in Lalapet, who will recommend an individual for employment. Positions in this process are diffuse and relate to aspects of caste, kinship and friendship, where friendship may sometimes be more effective than kinship.

Lalapet's migration stream depends on maistr ${ }^{10}$, who differ from those of the debtbondage system (Picherit 2009): they have no links to the village, provide no monetary advances, come from other districts and recruit only at Lalapet's adda (the place where labourers gather and wait for job). The personal relationships that labourers are able to establish with the maistri are key not only for the recruitment process but also for the caste. Short-term migration requires a mechanism for bypassing networks in order to perpetuate the migration stream. All Gollas are aware of the importance of Lalapet for their family, caste and the village economy.

\section{Discipline in the Informal Urban Economy}

The informal regulation of labour migration affects how labourers engage with the urban construction industry, the organization of which excludes them from establishing long-term projects in cities. Village relationships contribute to constraining resistance within urban settings just as much as indirect labour management and State absence.

Lalapet is both a residential neighbourhood and an adda and it is necessary to work for a maistri in order to access the neighbourhood, jobs and local facilities. The only way to stay in the 
urban informal economy is to negotiate multiple hierarchies (maistri, neighbours and shopkeepers).

This section of the paper explores the relationships between labourers, maistri and the neighbourhood. It shows how the Golla's social and spatial mobility strategies conform to the principles of discipline and dependency, which are indispensable for ensuring a long-term, sustainable caste presence (at the collective level) in the urban construction industry and Lalapet. These principles are indivisible from labour organization, as access to work and living spaces are one and the same thing. Multi-facetted elements of collusion, dependency and conflict characterise the ambiguous, temporary relations between labour and maistri.

\section{NICHES AND STEREOTYPES}

The Gollas are recruited in large part thanks to their reputation and 'label' as Palamur labourers, which all Golla labourers proclaim in Lalapet. Palamur is the former name of Mahabubnagar district, a name which was given to debt-bonded labourers working on construction projects (Olsen 2000). This forged identity has nurtured class solidarities at the district level and become an acknowledged 'label' in Hyderabad's construction industry. Scholars, the press and media have all greatly contributed to this label with regular, somewhat romanticised articles praising the labourers for leaving their villages to toil all across India on canals and dams: 'their foundations are embedded with the sweat and toil of the renowned Palamur labourers' (quoted by N. J. UshaRao 1993: 1).

The name is nowadays applied to all manual labourers working in the construction industries, and a badge of pride for labourers for their physical effort and stamina in harsh conditions, and which they use to promote themselves as a docile, hardworking workforce to the maistri. This leads to collusion between labourers and maistri in favour of positive stereotypes and is contrasted to the putative under-commitment, absenteeism or rural attachments of other labourers (Chandavarkar 1994). Ramakrishna, a maistri:

'Only Palamur workers are trustworthy. Trust is important. They may leave and come back but would send someone else. Workers from Nizamabad or Warangal always complain. But Palamur know the work and need money, they are poor'.

Such stereotypes facilitate the recruitment process for the Gollas, and the maistri are very keen to praise their labour when negotiating with construction managers. They market a Palamur labour force rather than a Golla workforce:

'They work hard and are very strong: I can go away and they would still be at work. And having Palamurs helps a lot with contractors to guarantee a good batch of labourers'.

The labourers thus shift constantly between caste, class and geographical identities depending on the context. The marketing of Golla as Palamur illustrates the everyday tactics used to establish a position on labour market. Krishnaïah evokes this sense of belonging to the same group with a common destiny: 
'We [Palamur] go and work everywhere. Kurmurti [Madiga] is in Karnataka, Chandraïah [Golla] in Nagpur and Venkata [Lambadi] in Thane. Palamur are like this, we work everywhere in India, it has always been like this, we toil but we [Golla] might buy goats. I do save money with my wife'.

\section{MAISTRI, LOCAL PROTECTION AND DISCIPLINE}

The low-caste maistri are extremely influential in this urban labour market. They come from various districts across Telangana and are paid a commission of 10 percent of workers' daily salaries; women workers are paid 25 percent less. This salary is however three times higher than for debt-bonded labourers.

The maistri control access to resources such as water and rented huts. Affiliation to a maistri provides a degree of protection from everyday difficulties and police harassment. Labourers' identities are thus decided not by the State, but by their relation to the maistri, who are the ones who gave the neighbourhood its raison d'être and who decide on the boundaries of the spaces they protect. Their protection facilitates obtaining small credit from shopkeepers and reinforces labourers' dependence. By controlling access to housing, work and water, and providing protection from the police, maistri only accept obedience from labourers. Losing one's job in Lalapet due to rebellion or seeking work elsewhere means losing a place in Lalapet.

Labourers are aware of what is required of them: docility, availability, signs of respect and deference are the tools for ensuring a good relationship with the maistri. The absence of any geographical, caste, kinship or debt relationships limits personal relations between the labourers and the maistri.

Chandraïah, a Golla daily-wager comments:

'When I used to migrate with maistris [as a debt-bonded labourer], the language and food may have been different, but my maistri would take care of everything. Here [as a daily-wager] we do not know him. He gives us work, we work and we do not talk much. My wife is in charge of food and water, and we do everything. The maistri does not bother us. He is not from my village'.

Relations are not shaped by a long history of dependencies. Possibilities to contest maistri and relations of friendship and joking testify to flexible relations structured by the power of the maistri to compose their daily workgroups.

Labourer group sizes vary between 10 to 15 men and women, whom the maistri select according to the work to be done, labourers' seniority in Lalapet, their reliability and personal relations. At night, the adda is the only public place the male labourers can access. There is a relaxed atmosphere there to consult with the maistri. Such consultations are a must, for discussing the work for the days ahead and to get paid (the money is given to the men).

This form of migration demands accepting domination, whether on worksites, at the addaor in living spaces. Such consent reinforces their reputation as docile, reliable and disciplined workers, and makes them attractive as employees. Furthermore, the seasonality of this migration, the recruitment modes and caste peer expectations in the village deter most forms of rebellion. The Gollas are accepted for their ability to behave according to expectations, namely as a poor labour workforce at the bottom of the urban informal economy. 


\section{KEEPING A LOW PROFILE}

This state of affairs means the Gollas must negotiate various caste and class hierarchies. Their relegation to the SC wada $^{11}$ zone of the former untouchable Madiga caste is the hardest part for the Gollas, who would never accept this in the village. Such proximity causes many conflicts with hut owners and neighbours, which the Gollas women in charge of domestic tasks handle. Men mostly spend their time at the adda, while the women stay at the huts before and after the working day for domestic tasks. They wake up at around 5:30 am and have to cook, fetch wood and water, take care of the children and clean the huts before leaving for work. Their tiniest activities are meticulously scrutinized by the middle-class Madiga women, who are always keen to criticize. Life in the huts demands conformity to neighbourhood rules and microhierarchies of caste. Golla Kondamma highlights the lack of respect they are shown, while stressing the Madiga's caste backgrounds:

'We are treated like dogs. But who are they? They blame us for everything, for water shortages, water leakages, lack of cleanliness, the noise. They even tell us how to cook the rice. Those people have just discovered rice and they would like to teach us'?

But Managamma also highlights the poor living conditions:

'We pay for everything, but they still complain. What can we do? The huts are in very bad shape, we struggle to get water and the toilets are a very long way away'.

Women have to cope not only with a double workload and the gendered divisions of space, but also the threat of male maistri and of neighbour's sexual remarks. They alternate between keeping a low profile and public outcries to ward off male aggression. They do not expect protection from their husbands in residential areas or the worksites: they always advocate for themselves. The women's determination does not prevent them from maintaining a low profile, and they remain on the defensive.

Male Gollas are in no better position at the adda, where they experience the violence of small shopkeepers, rickshaw drivers and others. The owner of a small bicycle shop explains the situation:

'I was a worker, but my factory closed down two years ago. I was a CITU [Centre of Indian Trade Unions] member. Now, I have only this shop, no pension, nothing. The Palamur work hard, but... who will come if they block the front of my shop'?

Everyone highlights the fact that the Gollas are workers at the very bottom of the social ladder: 'They are illiterate and know nothing. They work hard, breed and die. That is their life'. Kurmaïah, a Golla who owns the local stationery store, considers them as foreigners: 'They claim to be Golla, to be Palamur, I don't know exactly. They come and go, how can we trust them'? 
Beyond insults, mockeries and comments there is often physical aggression. Shopkeepers keep wooden sticks for driving the labourers away to other shops. Police officers also use sticks and are always willing to support the shopkeepers against the migrants. Keeping a low profile is thus the best tactic for labourers to avoid conflict. In the morning as they wait for jobs, the labourers find themselves trapped between the shopkeepers and dense traffic. I saw bus drivers pushing the labourers, and rickshaw drivers amusing themselves by splashing them in the rainy season.

Such violence boosts the labourers' bid for invisibility, but also reinforces the boundaries of Lalapet, which the maistri manage to negotiate with the police by providing a relational identity: 'they are my labourers'. The labourers' awareness of being at the bottom rung of the informal economy is always contrasted to their experiences of village life, or to debt-bondage. Krishnaïah: 'People speak to us harshly, telling us what to do and treating us like biccagadu [beggars]. In the village, if someone attacked us, we would answer back'.

Those discourses stress how fear is a subtle and powerful instrument of domination, making harder contestations in informal urban economy. Village, in contrast, is represented as a known environment where labourers have a grasp of informal mechanisms.

Idanna, a debt-bonded labourer, describes Lalapet as conflict-ridden:

'There are constant squabbles over water, food or whatever. They complain because I cut this, or I killed this, or I piss here or there. You pay for everything and the huts belong to the Madiga'.

Migrants are always held responsible for theft or conflict, but such social divisions are based on caste and class: 'We work for money and to eat. We work for food. I don't eat their food and they don't eat mine. Why would they come to my hut'?

Idanna favoured debt-bondage because the maistri were completely in charge of the food, workload and housing, but his wife differs:

'There is no profit. What is the point? My daughters are in Lalapet; there I could choose my food and the work is easier. But Idanna does not want that. I have three daughters to marry, I have 80000 rupees of debt and he does nothing but drink'.

Ultimately, the labourers adapt to local conditions by staying in the shadows. The tea stall in Lalapet where they gather is at the end of a dead-end, and invisible to outsiders. They consume alcohol in their huts, which are a familiar space in comparison to wine shop courtyards. Drinking outside demands both time and confidence, as do showing off new clothes, fashion items or new hairstyles: they instead show off consumer goods purchased in Lalapet in their village of origin.

While Idanna rejects the daily wager status, other Gollas comply with Lalapet' social codes of discipline to consolidate networks and relations with the maistri, and to meet village caste expectations. Informal urban economy work is just as much a matter of housing and citizenship as mere employment relationships. The construction industry is organised via the hierarchical delegation of labour management to the maistri, who stifle migrant demands or collective organisation, and control both their places of work and urban environment. Dailywagers have to accept dependency in order to get work, housing and an identity in the urban 
setting. The absence of State regulation of labour standards in the construction industry is matched by an absence of rights in the city.

\section{BEYOND LALAPET: URBAN SPACES AND WORKSITES}

Protection-identity as an issue is most marked outside the confines of Lalapet. Labourers' feelings of vulnerability are manifest in the way they travel across the city, moving as a group and avoiding main roads, walking across wastelands and along railway lines or other paths avoid encounters.

During the high season (summer), 200 workers gather at around 7 am in three groups in Lalapet's main square. The first group consists of 40 local workers from the north of Telangana. The second consists of qualified workers (masons, painters etc.) who settled permanently in Hyderabad, and the third of Golla labourers who wait at the roadside, trapped between the shops and the traffic jams. They are the only group to work with the maistri and are at the bottom of the hierarchy as the cheapest labour force. They avoid interacting with the other groups.

Each morning, the Gollas gather their work tools and tiffin boxes and wait for the maistri to come and tell them their place of work, which changes every day. On the particular day to be described here, fifteen of us left along the railway track. A few hundred meters later, we crossed an area of wasteland which ran alongside a water tank, and squeezed through a broken wall. The maze of streets and houses opened onto disused sheds and wasteland. Kurmaïah explained:

'The main road is full of people who complain. But we have to work; the maistri don't give money for the bus. On the tracks, nobody bothers us. If someone harasses our wives, what could we do? There, nobody knows the maistri. Hyderabad is dangerous, like Bombay; we have no money and the police never help us'.

We walked for a few kilometres, interspersed with silence, jokes and comments on the landscapes, temples and mosques we passed. The maistri then arrived by scooter at the building. The labourers change buildings every day, cementing roofs and then moving on to the next project. There are always three maistri involved (for labour, the machinery and scaffolding), who often disappear to work at other building sites.

The pace of the work was agreed according to the machinery and material available. The building's owner asked the maistri to oversee the labourers, who would work on the roof for 8 hours under the sun. The maistri declined and indicated his authority by threatening the group as well as praising them. He needed autonomous labourers in order maintain his position. The work was divided between two groups, one of which supervised and loaded the machine with sand and stones; the other on the roof dispatched the cement. When the work downstairs slackened off, the men and women on the roof took the time to chat, sit and smoke, before checking. Ingenious spatial practices were needed to take a break, which had to be adapted to everyone's changing environments and spatial positions. In contrast to factories, the labourers had no prior knowledge of the site and had to invent ways to hide from the maistri and owner in order to smoke in the shade, or resting by pointing out the distance to the toilets, or getting lost. Playing with space and the intensity of work put pressure on the owner, who became worried about the work's noncompletion, and who tried to negotiate tea and snacks, a cost the maistri refused to meet. Labourers negotiate at the margins and are always crudely reminded of their structural position in the urban informal economy. 
In the afternoon, four semi-qualified labourers from Lalapet joined the group, dressed in work trousers and plastic boots and bringing their own tools. They rolled out fresh concrete that was carried over by Golla women. Labour hierarchies were in full evidence: a labourer who was splashed by concrete suddenly yelled at a woman. She did not reply, but the roof fell silent. She carried on working and returned to spread concrete, upon which the worker began to insult her. She then threw down her container and shouted back, supported by the other women. The Golla men watched on at a distance, while the maistri calmed everyone in order to avert a conflict with Lalapet's semi-qualified labourers.

Later that evening, as the male labourers dismantled the scaffolding, two maistri discussed money with the owner. The amount was fixed on a 'square foot' basis and the maistri had to evaluate the number of labourers required to cover the surface. None of them revealed the amount to the labourers. The owner reminded the maistri of the cost of electricity, water and the money spent on tea, snacks and machine puja. The maistri pointed out that he had brought two extra labourers and pushed for a higher amount, but the owner refused to pay for what he considered the maistri's mistake.

Many of the labourers had already left and the maistri informed Saodanna of the situation: 10 rupees less per labourer, due to the owner cheating. Saodanna became enraged and demanded the maistri return the full amount. When he refused, Saodanna and two other labourers shouted at him to reimburse them with his own money. Their anger increased and the maistri declared that he would not have a job for them the following day. Saodanna was ready to fight but was now dropped by his colleagues. He continued alone, claiming that he would make the matter public to other maistri and labourers.

None of the labourers ultimately received their anticipated salary. On the adda, another maistri guaranteed him work:

'He wanted to give me 50 rupees to shut up. It does not work like this, we work together, the group is important, I cannot take money away from the others. Krishnaïah helped me to come here, how could I make money on his back'?

Saodanna refused the offer but kept quiet. His position depends on the perception of being part of a broader process of migration involving both caste and village. Saodanna always bears in mind future migrants and the need to secure them a place.

Nothing there complies with State labour regulations and everything is informally regulated, be it tea breaks, work undertaken, salaries, working conditions, toilets, breaks, timing or mobility. Occupational health and safety, minimum wages, regulated working hours, and employment security are all denied to labourers. There are no safety helmets, safety nets, shoes, ropes and/or equipment, nor ILO recommendation-listed equipment for construction workers.

Discipline and keeping a low profile in urban settings are crucial to keeping this work stream open, and is always subject to uncertainty, fear and arbitrariness. The lack of protection in cities and worksites - be it from the State, trade unions, or NGOs - combined with recruitment and caste relations in the village, limit labour issue struggles to everyday forms of resistance and negotiation. The goal is to guarantee employment in Lalapet and to claim social and development outcomes when back in the village. 


\section{Political Fights for Social Outcome in the Village}

The Golla's acceptance of domination in Lalapet contrasts their political demands and self-promotion in their village, where they brandish their know-how and knowledge of migration and cities, participating in the village's religious, economic and political life. Migration is promoted as a sign of cultural flexibility, the ability to negotiate multiple cultural codes and to migrate without maistri or the patronage of a Reddy.

The highlighting of cultural, social and political areas nuances the limited remittances. They are able to save and invest hundreds of rupees: only those going to Lalapet with family assets manage to do well. Others have to repay debts to the moneylenders and to former maistri. The ambitions of daily wagers are also hit by the costs of religious festivals, weddings, health and housing, while investments in agriculture are risky: a drilled well may turn out dry, while only bonded labour can get an advance of 20000 rupees.

Labourers instead capitalise on their experiences in Lalapet by way of their selfconfidence, their body language, the language they use and their involvement in local affairs. They use their re-entrance into village power relationships to ensure a better position within the caste and in the village. They do this firstly to differentiate themselves from lower castes such as Madigas and from debt-bonded labourers, and secondly to secure temporary sources of protection via access to development schemes. The Gollas then mobilise caste and political networks, actively participating in religious festivals and political affairs to display their affiliation to the leading party.

The wide variety of development schemes launched by the TDP and Congress from the 1990s till today has strongly reinforced local political clientelism and the power of rural leaders, who control and redistribute profits (after taking a substantial percentage). It is well established that development schemes which run through political parties cut universal rights into electoral categories. Under TDP and Chandababu Naidu leadership, from 1994 to 2004, those schemes concerned 'livelihood issues' such as food, health, education or water or skill development and marketing support, such as deepam (light) which provides cooking stoves for women, adarana with tool kits for artisans, or water users' associations, school committees, microcredit, (Srinivasulu 2004, Suri 2005, Mooij 2005). Y.S.Rajasekhara Reddy, the Congress leader from 2004 to 2009, pursued such policies and launched a large number of development schemes related to pension, housing and health. He also pushed ahead with the National Rural Employment Guarantee Act (NREGA) (supposed to guarantee hundreds days of work in rural areas) and the Rajiv Aarogyasri Community Health Insurance Scheme. The latter scheme intends to provide free chirurgical care to the poor, by funding the private and corporate hospitals and reducing the budgets of primary health centres (Mitchell et al. 2011, Shukla et al. 2011). Those are some of the schemes that have deeply reinforced competition and divisions in the village, between political parties as well as within castes. The access to ration cards and other schemes is not a right (as it should be, formally): access is provided through subtle and endless negotiations and manipulations of local micro-hierarchies, from caste to individual levels. To secure access to those programs after months in Hyderabad, migrant labourers have to display their support to the TDP party (who hold power at the village and district level), while henchmen of the party ensure the votes of the caste.

The State is not a monolithic block, and its policies are constantly re-interpreted by government agents and bodies, as well as by the local leaders in charge of the programmes. Furthermore, the everyday relations between State, labour and politics are strongly mediated by 
goondas (middlemen) who enjoy proximity to both leaders and labourers. They regulate access to the State, to credit, NGOs, jobs and other resources, with a clear preference for people affiliated to their party (Michelutti 2008). N. Reddy is one such goonda, the grandson of the village's main moneylender, combining many activities. He is a close associate of the head of the village and the Village Development Officer, mobilises supporters for political meetings, collects migrants' debts, and is in charge of collecting microcredit group funds at the Cluster level, which his mother directs. Through long-standing docility to the head of the village and a mixture of violence and protection towards the low-castes (Alm 2010), in 2009 he managed not only to become the manager of the shop for subsidized products (petrol, rice, etc.), products which he sells for own profit in the nearby town, but also became a main agent of NREGA. Within NREGA, on average 10 to 15 days of work is carried out per year, in contrast to the 100 days planned and charged. This clearly demonstrates the diversion of money within the scheme and its importance as a source of corruption.

In this context, labourers' struggles in the village are directed at reframing such microhierarchies in order to obtain a better share of development activities, and to access goods, whether products, ration cards, housing or health schemes. These actions however scarcely challenge existing local hierarchies.

Religious festivals represent a major opportunity to display success and political power, as well as affiliation and support. Most of the Golla labourers come back for major festivals, such as Ganesh and Shankranti: those who cannot afford to do so stay in Lalapet. Migration narratives, confident body language, and new clothes bought in Hyderabad are all displayed.

Chinna Kondanna, a young Golla, returned to the village a few months after his first experience as a migrant labour, wearing trousers and a shirt, and was excited to describe to his family: 'I have seen planes in Begumpet, I went to the zoo, by bus. I also worked in High Tech city on 6-storey buildings'.

This type of narrative is common but while bonded labourers compile a catalogue and map the Indian major projects on which they have worked, daily wagers highlight their mobility in the city. Citing place names and modes of transport displays their migration knowledge and know-how, which serves as a challenge to the former exclusivity of the knowledge of middlemen. It distinguishes the Golla daily wagers from bonded labourers, who have no clue of their destination before the day of their departure.

The entire village is well aware of the Gollas' return, as they celebrate their first night with excessive alcohol consumption in public places. They can be heard shouting, laughing, fighting and crying, and visiting their kin and caste fellows.

Migrant labourers are the most active participants of religious festivals, taking part in all caste activities, from meetings to rituals. They can always be found at the front, stressing their caste identity and sentiments in dance, songs, and other ways. On the last day of Shankranti, Krishnaïah, Saodanna and others from Lalapet, dressed in traditional clothes, gathered in front of the house of the head of the village. They then started singing praises to his late son. This continued all day and they went from house to house among the TDP, the Madiga and the maistri. The recital was peppered with dancing, songs and cries, as well as regular stops at the palm wine shop. Such visits ensure a visible presence in the village and expresses support to local leaders.

This process is clearly explained by N. Reddy, who is charged with drumming up support during the politico-religious festival of Ganesh: 
'There would be three Ganesh. The TDP Ganesh at the temple, the Congress Ganesh at the Village Committee Hall and then the Madiga. Last month, there was a fight during the Village Education Committee meeting. There were one hundred people, Congress and the TDP, it lasted 25 minutes... There will be other fights. Elections come next year, we have to win. If the TDP wins, there will be money for development and I will get a job. I am in charge of everything; I go to Lalapet, bring the migrants, give money and put them back on the bus. They know what we do for them, they have to support us'.

During the festival, the Gollas also celebrated the recently sanctioned Golla Committee Hall ${ }^{12}$, which symbolises their new status in the village. The nine days of the TDP's Ganesh (compared to the five days of the Congress) was a huge success for the party: every night, 200 people gathered around the TV displayed at the Ganesh stand, while the Gollas danced and sung into the middle of the night.

Such visibility brings conflicts with the Reddys of the Congress party, in particular the young sons of landowners, who migrate as tractor drivers and machine operators to building sites or mines. Many feel threatened by the social rise of the Gollas. The TDP's success and the Golla's presence reinforce tensions. N. Reddy's prediction bore out on the final night when 70 men and women armed with wooden sticks, mainly Gollas migrant labourers and young Reddys of Congress, fought for an hour by the TDP Ganesh. The police only came after the TDP leaders of surrounding villages arrived on the scene, while wounded Gollas were exhibited in the courtyard of the head of the village. The leaders of the Congress were jailed for a month, the young ones expelled from the village for the same period, while no TDP members were arrested.

Such physical and open confrontation with the Reddys contrasts to the Gollas' attitudes in Lalapet, and highlights changing caste and political relationships. Politics is key to accessing development projects and building up a clientele, which receives an unequal and hierarchical share. The Golla labour migrants' demands and struggles are focused on the village where State interventions are deployed. The State is embedded into village power relationships, as local leaders control programs. The main task of N. Reddy, the agent of this development, is to support the social rise of the Gollas while keeping them at their level. The Gollashave yet taken some benefits from health, housing, education, ration cards and other products. However those schemes have considerably reinforced the power of local leaders who keep the largest part of schemes, strengthening inequalities between leaders and labourers.

\section{Conclusion}

This ethnography of seasonal migrant labourers has stressed that labour struggles, working and living conditions in urban informal economy are shaped by the interrelationships between construction industry, informal regulation of migration and labour, and local village leaders' direct control over development issues. It points out how labour migration, politics and development are related in the everyday life of labourers, from village to urban migration sites, and how capital/labour issues have become silenced in favour of development/poverty struggles.

The informal management of migrant labourers fits within the capitalist logics of the construction industry and its interrelated modes of domination. This organization, combined 
with the absence of rights in the city, hampers labourers' demands for improved working and living conditions or salaries. In a context of informal rules and politics of fear, discipline and maintaining a low profile are the only options to secure a migration stream in the absence of State regulations of labour standards, trade unions and other civil society movements. Safety, health, salaries, working hours, security, migration, housing, water and electricity are all informally negotiated in a harsh power relations context.

This paper also shows how the absence of labour standards and regulation are strongly linked to the place given to migrants in the city. The impossibility of engaging in struggles in the urban informal economy due to isolation, fear and forms of dependence in urban settings (Lerche 2010, Heyer 2000) contrasts with their visibility and contestations in the villages where social programmes are mostly focussed (e.g. NREGA). Labourers have a subtle knowledge of informal mechanisms of political clientelism needed to obtain social outcomes. The social mobility of Gollas, from debt-bonded to daily wage labourers, involves greater contestations in the village, mainly to 'enact, re-inscribe and consolidate traditional arrangements' (Gidwani and Sivaramakrsihnan 2003: 362). The acceptance of reformulated hierarchies and disciplines, both at work and in the neighbourhood setting, is transformed into an advantage in caste politics and development in the village. However, a large proportion of village leaders, MLAs and MPs in Mahabubnagar district (and beyond) have built their fortune as construction sector contractors and their control of politics also leads to schemes, the key of redistribution and votes: struggles in the village focus on redistribution articulated around caste, not on the organization of redistribution.

\section{ACKNOWLEDGEMENTS}

An earlier draft of this paper was presented at the Geography seminar of the University of Sussex and I am very grateful to Geert De Neve for comments. It was also presented at the 21st European Conference on Modern South Asian Studies, Bonn, July 2010: thanks to the participants for their comments. I wrote the paper thanks to a postdoctoral fellowship at the Cluster of Excellence Asia-Europe of the University of Heidelberg. Special thanks to Isabelle Guérin, Jens Lerche and Ravi Srivastava and the anonymous reviewers for their pervasive comments, as well as to Jane Weston for the editing.

\section{NOTES}

1. The Telugu Desam Party is a regionalist party created in 1982 by N.T. Rama Rao, a famous movie hero, and lead by Chandrababu Naidu from 1994. From then, Congress party and TDP alternate to govern the State of Andhra Pradesh (TDP from 1994 to 2004 and Congress from 2004 to present). However, TDP hold power in Mahabubnagar district. 
2. Andhra Pradesh was the first regional State to receive direct funding from World Bank in the 1990 s.

3. Although this has now collapsed spectacularly.

4. The control exercised on economic and social attitudes - calculating, saving, entrepreneurship spirit, productive investment, reimbursement - has recently lead in Andhra Pradesh to suicides and attacks on credit agents and microfinance offices, pushed to strengthen their tight control on credit to adapt to financial markets.

5. This is a hereditary title.

6. The kinship links soften the defeat of TDP and guarantees some public contracts. Due also to his hereditary title, the head of the village manages to maintain local factions relatively stable, even if political competition greatly increases over the years.

7. This is the nearby town, also subdistrict headquarter.

8. Scheduled Castes. In the village, Madiga is the main vernacular term with harijan. In Lalapet, harijanwada is the common denomination by upper castes, while inhabitants prefer SC wada. Golla labour migrants conserve Madiga. Dalit is barely used in the village and in Lalapet.

9. It consists in loading and unloading trucks.

10. From now on, unless further explanations are given, 'maistri' only refers to labour middlemen operating in Lalapet.

11. The S.C. wada is the area where the S.C. live in segregation from other castes.

12. Committee Hall is a public and secular meeting place for the entire village. Gollas hold their meetings at the main temple under the banyan. The construction of a specific place reserved to a community has caused diverse conflicts.

\section{REFERENCES}

Alm, B. (2010) 'Creating Followers, Gaining Patrons: Leadership Strategies in a Tamil Nadu Village', in P. Price and A.E. Ruud (eds) Power and Influence in India. Bosses, Lords and Captains (pp. 1-19). New Delhi: Routledge.

Augsburg, B. and Fouillet, C. (2010) 'Profit Empowerment: The Microfinance Institution's Mission Drift', Perspectives on Global Development and Technology 9(3-4): 323-351. 
Bowles, P. (2010) 'Globalization's Problematic for Labour: Three Paradigms', Global Labour Journal 1(1): 12-31. Available at : http://digitalcommons.mcmaster.ca/globallabour/vol1/iss1/3 (accessed 10 November 2011).

Breman, J. (1996) Footloose Labour. Working in India's Informal Economy. New York: Cambridge University Press.

Breman, J., Guérin, I. and Aseem, P. (eds) (2009) India's Unfree Workforce. Old and New Practices of Labour Bondage. Delhi: Oxford University Press.

Byres, T. J., Kapadia, K. and Lerche, J. (eds) (1999) Rural Labour Relations in India. London: Frank Cass.

De Neve, G. (2003) 'Expectations and Rewards of Modernity: Commitment and Mobility Among Rural Migrants in Tirupur, Tamil Nadu', Contributions to Indian Sociology (n.s) 37(1-2): 251-280.

Frykenberg, R.E. (ed) (1977) Land Tenure and Peasant in South Asia. New Delhi: Orient Longman.

Gidwani, V. and Sivaramakrishnan, K. (2003) 'Circular Migration and Rural Cosmopolitanism in India', Contributions to Indian Sociology (n.s.) 37(1-2): 339-367.

Gooptu, N. (2007) 'Economic Liberalisation, Work and Democracy: Industrial Decline and Urban Politics in Kolkata', Economic and Political Weekly 42(21): 1922-1933.

Guérin, I., Roesch, M. and Servet, J.M. (2009) 'Microfinance, Financial Inclusion and Social Responsibility' in de H.-C. Bettignies and F. Lépineux (eds) Finance for a Better World. The Shift Toward Sustainability (pp. 7-29). London: Palgrave Macmillan.

Harriss, J. (2005) 'Political Participation, Representation and the Urban Poor: Findings From Research in Delhi', Economic and Political Weekly 40(11): 1041- 1054.

Harriss-White, Barbara (2010) 'Globalization, the Financial Crisis and Petty Production in India's Socially Regulated Informal Economy', Global Labour Journal, 1(1): 152-177. Available at: http://digitalcommons.mcmaster.ca/globallabour/vol1/iss1/9 (accessed 12 November 2011).

Herrenschmidt, O. (2004) 'Ambedkar and the Hindu Social Order', in S. Jondhale and J. Beltz (eds) Reconstructing the World: B.R. Ambedkar and Buddhism in India (pp. 37-480. New Delhi: Oxford University Press. 
Heyer, J. (2000) 'The Changing Position of Agricultural Labourers in Villages in Rural Coimbatore, Tamil Nadu, Between 1981 and 1996', QEH Working Paper 57, Oxford: University of Oxford.

Indian Planning Commission (2007) Five Year Plan 10 $0^{\text {th }}$, volume 2, Chapter 7. Available at: http://planningcommission.nic.in/plans/planrel/fiveyr/10th/volume2/v2_ch7_7.pdf (accessed 15 November 2011).

International Labour Organisation (1988) Safety and Health in Construction Convention. Available at: http://www.ilo.org/ilolex/cgi-lex/convde.pl?C167 (accessed 16 November 2011).

Lerche, J. (2007) 'A Global Alliance Against Forced Labour? Unfree Labour, Neo-liberal Globalization and International Labour Organization', Journal of Agrarian Change 7(4): 425-452.

Lerche, J. (2010) 'From Rural Labour to Classes of Labour. Class Fragmentation Caste and Class Struggle at the Bottom of the Indian Labour Hierarchy', in B. Harriss-White and J. Heyer (eds) The Comparative Political Economy of Development: Africa and South Asia (pp. 64-85). London: Routledge.

Michelutti, L. (2008) The Vernacularisation of Democracy: Politics, Caste and Religion in India. London/Delhi: Routledge.

Mitchell, A., Mahal, A. and Bossert T. (2011) 'Healthcare Utilisation in Rural Andhra Pradesh', Economic and Political Weekly 46(5): 15-19.

Mooij, J. (ed) (2005) The Politics of Economic Reforms in India. New Delhi: Sage Publications.

Mosse, D. (2005) 'On the Margins in the City. Adivasi Seasonal Labour Migration in Western India', Economic and Political Weekly 40(28): 3025-3038.

Olsen, W.K. and Murthy, R.V. (2000) 'Paper on Contract Labour and Bondage in Andhra Pradesh (India)', Journal of Social and Political Thought 1(2). Available at: http://www.yorku.ca/jspot/2/wkolsenrvramana.htm (accessed 16 November 2011).

Pattenden, J. (2005) 'Trickle-down Solidarity, Globalisation and Dynamics of Social Transformation in a South Indian Village', Economic and Political Weekly 40(19): 19751985.

Picherit, D. (2009), “'Workers, Trust Us!": Labour Middlemen and the Rise of the Lower Castes in Andhra Pradesh', in J. Breman, I. Guérin and P. Aseem (eds) India's Unfree Workforce. Old and New Practices of Labour Bondage (pp. 259-283). Delhi: Oxford University Press. 
Rao, N.J.U. (1993) Palamur Labour: A Study of Migrant Labourers in Mahabubnagar District. Hyderabad: Council for Social Development.

Robinson, M.S. (1988) Local Politics: The Law of the Fishes. Delhi: Oxford University Press.

Shukla, R., Shatrugna, V. and Srivatsan, R. (2011) 'Aarogyasri Healthcare Model: Advantage Private Sector', Economic and Political Weekly 46(49): 38-42.

Srinivasulu, K. (2002) 'Caste, Class and Social Articulation in Andhra Pradesh. Mapping Different Regional Trajectories’. Overseas Development Institute: Working Paper 179.

Srinivasulu, K. (2004) 'Political Articulation and Policy Discourse in Elections Andhra Pradesh', Economic and Political Weekly 39(34): 3845-3853.

Srivastava, R. and Sasikumar, S. K. (2003) 'An Overview of Migration in India, Its Impacts and Key Issues', Dhaka: Refugee and Migratory Movements Research Unit, London: Department For International Development, Paper $n^{\circ} 2$, Migration, Development and Pro-Poor Policy Choices in Asia. Available at: http://www.eldis.org/vfile/upload/1/document/0903/Dhaka_CP_2.pdf (accessed 15 November 2011).

Suri, K. C. (2005) 'The Dilemma of Democracy: Economics Reforms and Electoral Politics in Andhra Pradesh', in J. Mooij (ed) The Politics of Economic Reforms in India (pp. 130-168). New Delhi: Sage Publications.

Thirumali, I. (2003) Against Dora and Nizam: People's Movement in Telangana, 1939-1948. New Delhi: Kanishka Publishers.

\section{BIOGRAPHICAL NOTE}

DAVID PICHERIT is an associated member of the Centre d'Etudes de l'Inde et de l'Asie du Sud (CEIAS-EHESS), Paris. He is currently on a post doctoral fellowship affiliated to SOAS Department of Development Studies. 